11-EXPERIMENTAL RESEARCH

ORIGINALARTICLE

Models, Biological

\title{
Comparison of two experimental models of urodynamic evaluation in female rats $^{1}$
}

\section{Comparação de dois modelos experimentais para avaliação urodinâmica em ratas}

\author{
Ana Beatriz Gomes de Souza ${ }^{\mathrm{I}}$, Haylton Jorge Suaid ${ }^{\mathrm{II}}$, Carla Adelino Suaid ${ }^{\mathrm{III}}$, Silvio Tucci Jrv ${ }^{\mathrm{Iv}}$, Adauto José Cologna ${ }^{\mathrm{v}}$, \\ Antonio Carlos Pereira Martins ${ }^{\text {VI }}$ \\ ${ }^{I}$ Fellow Master degree, Division of Urology, Department of Surgery and Anatomy, Ribeirão Preto Faculty of Medicine, University of São \\ Paulo, Brazil. \\ II PhD, Associated Professor, Division of Urology, Department of Surgery and Anatomy, Ribeirão Preto Faculty of Medicine, University of \\ São Paulo, Brazil.

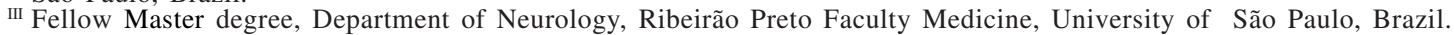 \\ Iv PhD, Associated Professor, Division of Urology, Department of Surgery and Anatomy, Ribeirão Preto Faculty of Medicine, University \\ of São Paulo, Brazil.
MD, PhD, Division of Urology, Department of Surgery and Anatomy, Ribeirão Preto Faculty of Medicine, University of São Paulo, \\ MD, Prazil. \\ VI Full Professor and Head, Division of Urology, Department of Surgery and Anatomy, Ribeirão Preto Faculty of Medicine, University of \\ São Paulo, Brazil.
}

\section{ABSTRACT}

Purpose: Urodynamic studies in small animals can be performed through urethral sounding or cystostomy. Objective: To compare the two methods of urodynamic evaluation in female rats. Methods: Ten female rats weighing on average $250 \mathrm{~g}$, under anesthesia with urethane $(1,25 \mathrm{mg} / \mathrm{kg})$ were submitted in three repeats to an urethal catheter of $0,64 \mathrm{~mm}$ in external diameter for cystometric measurements of vesicle pressure(VP1) and contraction time (CT1). The catheter was extracted at a constant velocity of $0.05 \mathrm{~cm} /$ minute until complete exteriorization and determinations of maximal urethral pressure (UP1) and functional urethral length (FUL1). This was followed by a cystostomy with catheter PE50 and a new determination of the vesical pressure (VP2). After bladder denervation, a new cystometric record indirectly infered the maximum urethral closure pressure (UP2). The peak urethal pressure (UP3) and the functional urethral length (FUL2) were determined in another urethral sounding. The pressure registration system consisted of a continuous infusion pump regulated to a flow of $0.1 \mathrm{ml} /$ minute connected both to the cystostomy catheter (PE-50) or the urethal catheter $(0.64 \mathrm{~mm})$ and the polygraph Narco-Biosystem. Statistical analysis employed the Wilcoxon non-parametric test Results: Mean VP1= 48,2 $\mathrm{mmHg}(11,8$ SD); Mean VP2 = 38,2 mmHg (9,0 SD) “p”" (VP1 X VP2) =0,0039. Mean CT1=30,2 s (21,5 SD); Mean CT2=20,0 s(7 SD) p (CT1 X CT2 $)=1,28$. Mean UP1 = 47,2 mmHg (6,5 SD); Mean UP2 =21,3 mmHg (6,6 SD), mean UP3 = 40,7 mmHg(13,3 SD) p (UP1 X UP2) = 0,002; “p” (UP1 X UP3) = 0,084; $\mathbf{p}(U P 2$ X UP3) = 0,002. Mean FUL1=14,2 mm (1,9 SD); Mean FUL2=14,1 mm $(1,9$ SD); $\mathbf{p}$ (FUL1 X FUL2) = 0,64. Conclusions: The methods employed to evaluate vesical and urethral pressures are different. The presence of the urethral catheter may be an obstructive factor. Surgical denervation up to the bladder neck level does not compromise urethral function.

Key words: Urodynamics. Pressure. Urethra. Bladder. Cystostomy.

\section{RESUMO}

Introdução: O estudo urodinâmico em ratas pode ser realizado através de sondagem vesical por via uretral ou por cistostomia. O objetivo deste estudo foi comparar estes dois métodos. Métodos: Foram utilizadas 10 ratas da raça Wistar, peso médio de 250 gramas, anestesiadas com uretana $(1,25 \mathrm{mg} / \mathrm{kg})$. Inicialmente foi realizado estudo por sonda uretral $(0,64 \mathrm{~mm}$ de diâmetro externo) para determinação da pressão vesical (PV1) e tempo de contração (TC1), após isto a sonda foi tracionada a velocidade constante $(0,05 \mathrm{~cm} / \mathrm{m})$ até sua exteriorização pelo meato uretral, avaliando-se a pressão uretral máxima (PU1) e o comprimento funcional uretral (CFU1). Fez-se, então, a cistostomia (sonda PE50) para determinação da pressão vesical (PV2). A seguir, realizou-se desnervação cirúrgica da bexiga e realizou-se novo registro cistométrico para se inferir a pressão uretral indireta (PU2). Logo após, foi passada sonda uretral para determinação da pressão uretral máxima (PU3) e do comprimento funcional uretral (CFU2). O sistema de registro das pressões foi constituído de uma bomba de infusão contínua regulada para $0,1 \mathrm{ml} / \mathrm{minuto}$ conectada em Y com o cateter de cistostomia (PE-50) ou cateter uretral $(0,64 \mathrm{~mm})$ a um polígrafo Narco-Bioystem. A análise estatística foi realizada através do método não paramétrico de Wilcoxon. Resultados: Média PV1= 48,2 mmHg (11,8 SD); Média PV2 = 38,2 mmHg (9,0 SD). “p”" (PV1 X PV2)=0,0039. Média TC1=30,2 s (21,5 SD); Média TC2=20,0 (7 SD) p (TC1 X TC2) = 1,28. Média PU1 = 47,2 (6,5 SD); Média PU2 = 21,3 mmHg (6,6 SD), média PU3 = 40,7(13,3 SD) p (PU1 X PU2) = 0,002; “p”' (PU1 X PU3) = 0,084; $\mathbf{p}$ (PU2 X PU3) = 0,002. Média CFU1=14,2 (1,9 SD); Média CFU2=14,1 (1,9 SD); $\mathbf{p}(\mathrm{CFU} 1$ X CFU2) = 0,64. Conclusão: Os métodos de avaliação urodinâmica são diferentes. A presença do cateter na uretra pode ser um fator obstrutivo. A desnervação cirúrgica, até o nível do colo vesical, não compromete a função uretral.

Descritores: Urodinâmica. Pressão. Uretra. Bexiga. Cistostomia.

1. Study performed at Department of Surgery and Anatomy, Division of Urology, Ribeirão Preto Faculty of Medicine, University of São Paulo ( FMRP-USP), Brazil. 


\section{Introduction}

Urodynamic studies are of great importance in the diagnosis of vesical and urethral disorders. International Continence Society (ICS) defines it as "the study of the physiology of the lower urinary tract and the hydrodynamics of urinary transport". ${ }^{1}$ Urodynamics in small animals (rats) is basic to the physiopathology of micturitional disorder studies, as well as to understand the effect of several drugs on the lower urinary tract. The literature considers two different methods for these studies, one of them through a cystostomy catheter (PE-50) "Y" connected to a continuous infusion system and to a polygraph. ${ }^{2}$ In this method it is possible to determine bladder pressure behavior during the filling up and emptying phases. In addition, the maximum urethral closure pressure can be indirectly determined. When the animal is submitted to the bladder surgical denervation up to the level of the bladder neck, the organ acts like a true reservoir. Thus, when the vesical hydrostatic pressure equals the urethral one, liquid is lost through the urethra and the maximum urethral closure pressure is registered.

Another method cited in the literature ${ }^{3}$ is related to performing the urodynamic study in female rats using catheter, $0.64 \mathrm{~mm}$ in external diameter, with two orifices, that are introduced via urethra, up to the bladder and "Y" connected to the continuous infusion pump system and the polygraph. In this way, vesicle behavior in the mictional cycle is determined. The catheter, when located in urethra and tractioned with constant speed until it is exterior to the urethral meatus, carries through the record of the urethral pressure profile (UPP). However, it should be considered that the presence of a catheter in the urethra may function as an obstructive factor to the mictional flow making the bladder contract with higher pressures.

Several experimental ${ }^{4}$ studies used UPP to evaluate drug influence on urethral function and in studies of infravesical obstruction. A study made in $2003^{5}$ using UPP evaluated the effect of the alpha 1 antagonists drugs, prazosin and phenoxybenzamine, on urethral function in beagle dogs. It verified the reduction of maximal urethral pressure and the maximal urethral closure pressure, 40 minutes after drug administration. UPP determination turned out to be an efficient and sensitive method to evaluate the effect of alpha 1 antagonists drugs on dog urethra.

Another $2006^{6}$ study verified the effect of muscarinic receptor antagonists (M1 to M4) on the physiology of the lower urinary tract of rats when administered by the cerebral intra ventricular way. Functional reactions were evaluated through cystometry and the urethral pressure profile. Results indicated that intracerebral ventricular administration of receptor antagonists M1 and M3 inhibited miction and that M2 e M4 antagonists had an excitatory effect on the lower urinary tract in conscious rats.

Cystometry and the urethral pressure profile had also been used to study the effect of alpha-blocker drugs on intra - vesical obstruction in female rats showing that significant reduction of bladder contractions was not inhibited and a greater urethral relaxation. ${ }^{7}$

The existence of these two methods and their wide use as reported in the literature, prompted the development of a comparative study in order to determine if they were equivalent or not. The present study aimed to compare vesical pressure measured by urethral catheters or cystostomy. In addition, the urethral pressure profile was compared before and after bladder surgical denervation.

\section{Methods}

Female Rattus norvegicus albinus, Wistar lineage, 08 to 12 weeks of age with an average weight of $205 \mathrm{~g}$ were obtained from the Central Animal Room in the Ribeirao Preto Campus of the University of Sao Paulo. They were used under anesthesia with urethane, i.p.in the dosage of 1, 25 $\mathrm{mg} / \mathrm{kg}$.

\section{Recording vesicle pressure through an urethral} catheter

A polyethylene catheter $(0.64 \mathrm{~mm}$ and $0.50 \mathrm{~mm}$ in external and internal diameters, respectively) containing a $0.1 \mathrm{~mm}$ lateral orifice, $1 \mathrm{~cm}$ from the occluded extremity was especially manufactured for the experiment. After vesicle emptying, the catheter was connected to a pressure transducer "Y" connected to a Narco-Biosystem polygraph and a continuous infusion pump with a flow of $0,1 \mathrm{ml} / \mathrm{min}$. The filling up and emptying pressure alterations were repeatedly recorded for three consecutive periods of time, with a 10 minutes interval between the measurements (Figure 1). The analyzed parameters were: maximum bladder pressure (VP1) and time of contraction (CT1).

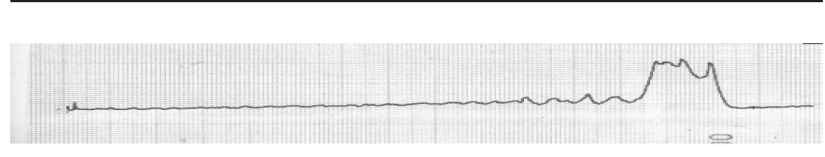

FIGURE 1 - Bladder pressure measured by an rethral cateter (VP1).

\section{Urethral pressure profile}

The polyethylene catheter $(0.64 \mathrm{~mm}$ in external diameter) was introduced through the urethra, the vesical content aspired and physiological saline at room temperature was infused at a flow rate of $0.05 \mathrm{ml} / \mathrm{min}$. The catheter was then tractioned out at a constant speed of 0.05 $\mathrm{mm} / \mathrm{s}$ until its exteriorization at the urethral meatus by a traction system consisting of a cotton wire connected to the traction pulley of the polygraph paper. Traction speeds of the catheter and the recording paper in the polygraph were equal, thus, evaluating the functional urethral length (Figure 2). Each animal was submitted to three consecutive procedures and the averaged findings were used to evaluate the results. The comparing parameters were: maximum urethral pressure (UP1) and functional urethral length (FUL1). 


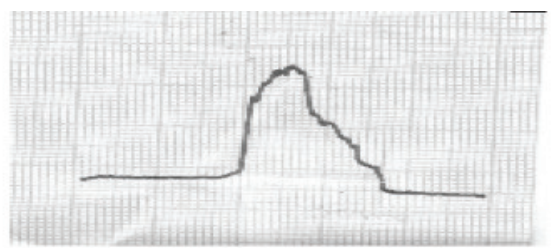

FIGURE 2 - Urethral pressure profile measured with the uretrhal cateter before surgical denervation (UP1). catheter

Recording vesicle pressure with the cystostomy

Cystometry was carried out through a cystostomy catheter (PE-50) after an initial abdominal trichotomy and suprapubic median laparotomy with $2 \mathrm{~cm}$ extension to perform cystostomy. The vesicle floor was repaired and through an opening $2.0 \mathrm{~mm}$ wide the polyethylene catheter PE-50 was introduced and fixed with a bag suture wire, Vicryl 5-0. After checking for leakings and catheter permeability, it was exteriorized by a counter-opening in the right back lateral region and fixed at this position with stitches of cotton 3-0 (Figure 3).

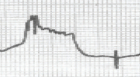

FIGURE 3 - Bladder pressure measured with the cystostomy catheter (VP2).

The pressure recordings were carried out through a continuous infusion pump $(0.1 \mathrm{ml} / \mathrm{min}) \mathrm{Y}$ connected to the PE-50 catheter and to a Narco-Biosystem polygraph. Each animal was submitted to three consecutive procedures with 10 minute intervals between each register and the evaluation of the results was made by averaging the findings. The parameters analyzed were: maximum bladder pressure (VP2) and time of contraction (CT2).

\section{Vesical Denervation}

The bladder was dissected up to the level of the bladder neck. The ureters were linked and sectioned closer to the bladder, maintaining the cystostomy .

Recording urethral pressure by the cystostomy catheter

A PE-50 catheter "Y" connected to a NarcoBiosystem polygraph and the infusion pump(flow of $0,1 \mathrm{ml} /$ s) carried out the recordings. Vesical content was aspired before starting the procedure. By surgical denervation the bladder became a pressure reservoir, allowing loss of liquid through the urethra when the bladder hydrostatic pressure equals the urethral closure pressure, and thus determining indirect urethral pressure. Each animal was submitted to this procedure three consecutive times, with 10 minute intervals between each recording, analyzing indirect urethral pressure (PU2) (Figure 4).

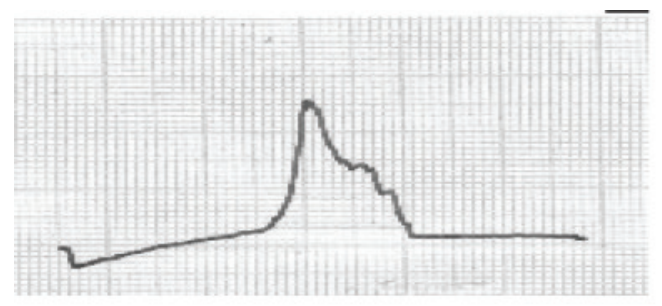

FIGURE 4 - Urethral pressure profile measured with urethral cateter after surgical denervation (UP3).

denervation.

Urethral pressure profile after bladder

The cystostomy catheter was occluded, and the polyethylene catheter introduced through the urethra. After vesicle content aspiration the catheter was connected in "Y" to the pressure recording system (Narco-Biosystem polygraph and the continuous infusion pump with a flow of $0.1 \mathrm{ml} / \mathrm{s}$ ). The catheter was out tractioned to a constant speed of $0.05 \mathrm{~mm} / \mathrm{s}$ until exteriorization of the perfusion orifice. Each animal was submitted to three consecutive procedures and the results evaluated by averaging the findings of maximum urethral pressure (UP3) and functional urethral length (FUL2) (Figure 5).

The averaged parameter values, in each animal were analyzed using the Wilcoxon non-parametric test. Animals were sacrificed by thoracotomy, still under anesthesia. All experiments respected the international rules for animal experimentation.

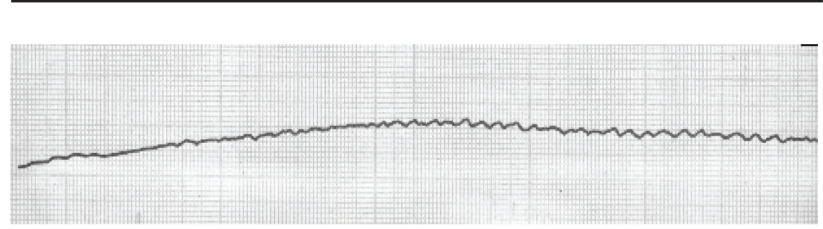

FIGURE 5 - Maximum urethral pressure measured with the cystostomy catheter (UP2).

\section{Results}

Mean vesical pressure values determined by the urethral catheter method were shown to be higher and significantly different from the ones obtained by the 
cystostomy catheter, $\mathrm{p}=0.003$ (Table1). The recorded values were, VP1 $=48.2 \mathrm{mmHg}$ (Figure 1) and VP2 $=38.2 \mathrm{mmHg}$

(Figure 2) respectively, for the urethral and cystostomy catheters. Mean vesicle contraction times measured by the urethral catheter $\mathrm{CT} 1=30,2 \mathrm{~s}$ or the cystostomy one CT2 $=$ 20,0 s were not significantly different " $p$ " $=0,128$ (Table 2).

TABLE 1 - Mean vesicle pressures by the urethral catheter (VPI) and the cystostomy catheter(VP2) in $\mathrm{mmHg}$.

\begin{tabular}{lll}
\hline & VP1 & VP2 \\
\hline Mean & 48,2 & 38,2 \\
SD & 11,8 & 9 \\
$\mathrm{~N}$ & 10 & 10 \\
\hline $\mathrm{p}=0,003$ & &
\end{tabular}

TABLE 2 - Mean contraction times with the urethral catheter (CT1) and the cystostomy catheter (CT2), in seconds.

\begin{tabular}{lll} 
& CT1 & CT2 \\
\hline Mean & 30,2 & 20,0 \\
$\mathrm{SD}$ & 21,5 & 7 \\
$\mathrm{~N}$ & 10 & 10 \\
\hline $\mathrm{p}=1,28$ & &
\end{tabular}

Bladder surgical denervation did not affect the values of the mean maximum urethral pressure since the recordings of the urethral pressure profile before UP1 = $47,2 \mathrm{mmHg}$ (Figure 3 ) and after the surgery UP3 = $40,7 \mathrm{mmHg}$ (Figure 4) were not significantly different "p"
$=0,13($ Table 3$)$.

Similarly, there was not a significant statistical difference between the mean functional urethral length in female rats before FUL $1=14,2 \mathrm{~mm}$ and after bladder surgical denervation FUL2 = $14.1 \mathrm{~mm}$, "p" = 0,64 (Table 4).

TABLE 3 - Mean maximum urethral pressure profiles before (UP1) and after vesicle denervation (UP3) expressed in $\mathrm{mmHg}$.

\begin{tabular}{lll}
\hline & UP1 & UP3 \\
\hline Mean & 47,2 & 40,7 \\
$\mathrm{SD}$ & 6,5 & 13,3 \\
$\mathrm{~N}$ & 10 & 10 \\
\hline $\mathrm{p}=0,13$ & &
\end{tabular}

TABLE 4 - Mean functional urethral length in female rats before (FUL1) and after vesical denervation (FUL2) measured in mm.

\begin{tabular}{lll}
\hline & FUL1 & FUL2 \\
\hline Mean & 14,2 & 14,1 \\
SD & 1,9 & 1,9 \\
$\mathrm{~N}$ & 10 & 10 \\
\hline $\mathrm{p}=0,64$ & &
\end{tabular}

Comparing the mean maximum urethral pressure in the pressure profile of normal female rats, UP1 = $47,2 \mathrm{mmHg}$, and the urethral pressure by cystostomy ,UP2
$=21,3$ in $\mathrm{mmHg}($ Figure 4$)$, a significant statistical difference was found, "p" =0,002 (Table 5).

TABLE 5 - $\quad$ Mean urethral pressures by urethral catheter in normal female rats (UP1) and by cystostomy catheter (UP2) in $\mathrm{mmHg}$.

\begin{tabular}{lll}
\hline & UP1 & UP2 \\
Mean & 47,2 & 21,3 \\
\hline $\mathrm{SD}$ & 6,5 & 6,6 \\
$\mathrm{~N}$ & 10 & 10 \\
\hline $\mathrm{p}=0,002$ & &
\end{tabular}


Mean urethral pressure by cystostomy (UP2 = $21,3 \mathrm{mmHg}$ ) and by the urethral catheter (UP3 $=40.7$ $\mathrm{mmHg})$ recorded in pressure profiles after vesical denervation showed a significant statistical difference "p" =0,002 (Table 6).

TABLE 6 - Mean urethral pressures by cystostomy (UP2) and by urethral catheter in female rats with denervated bladders (UP3). $\mathrm{N}=10$ female rats

\begin{tabular}{lll}
\hline & UP2 & UP3 \\
\hline Mean & 21,3 & 40,7 \\
$\mathrm{SD}$ & 6,6 & 13,3 \\
$\mathrm{~N}$ & 10 & 10 \\
\hline $\mathrm{p}=0,002$ & &
\end{tabular}

\section{Discussion}

Easy animal manipulation and urethra catheterization were two decisive aspects in the choice of female rats as experimental work animals. ${ }^{8}$

Urethane (ethyl carbamate), the anesthetic used is a derivative of aliphatic alcohols, having a hypnotic effect that causes depression in the nervous central system. ${ }^{9}$ This depression, however, is not important in relation to the vesicle function evaluated, as its reflexes are present in all animals. In a previous study urethane was considered more physiological than ketamine in experiments with cystometry evaluation and urinary pressure loss in conscious or under anesthesia normal female rats. ${ }^{10}$

The method used in female rats cystostomy is classic and widely mentioned in the literature, ${ }^{11}$ although bladder surgical manipulation could be pointed out as a disadvantage of the method. The presence of the cystostomy catheter, and the suture, if not made in a rigorous form, may reduce vesicle capacity by reducing its area, possibly causing an increase of the miction frequency. ${ }^{12}$

Vesicle trauma is minimized in this study by the use of bag suture. Another advantage in the method is the catheter in the urethra, which could act as an obstructive factor in vesicle emptying.

The classic technique described in the literature for urodynamic studies in humans ${ }^{13}$ was adapted to small animals and applied in diverse experimental conditions, demonstrating good reproducibility and a similar anatomicpharmacological correlation as is observed in the original report. ${ }^{14}$

Urethral evaluation "in vivo" was made possible by this adapted methodology, otherwise obtained with invasive techniques by surgical manipulation. Easy urethral catheterism is one of its advantages, although the possibility of urethral and/or vesical trauma during sound introduction should not be discarded. In addition,the catheter in the urethra increases its resistance to vesicle emptying and the physiological reply to obstruction is the increase of vesicle pressure to overcome the obstacle, which in turn modifies the real pressure values.

Vesical pressure values determined with the urethral catheter (PV1) were higher than the ones by the cystostomy catheter (PV2). The urethral catheter manufactured in the laboratory of experimental surgery with a $0.64 \mathrm{~mm}$ external diameter, should be a discrete obstruction factor in the female rat urethra having a diameter up to 2 $\mathrm{mm}$. In a 2004 experimental study form the urethral obstruction was induced in Wistar female rats through two catheters of $0,85 \mathrm{~mm}$ of diameter, resulting in an urethral bore of $1,7 \mathrm{~mm} .{ }^{15}$ This diameter is considered as an obstruction of moderate intensity while an urethral bore of $1,90 \mathrm{~mm}$ would be a serious obstruction. ${ }^{16}$ Thus, considering Laplace's law which relates the resistance of a tube with its length and diameter, showing that resistance is directly proportional to length and inversely proportional to diameter. ${ }^{17}$ the urethral resistance would increase as long of the catheters reduces its functional urethral diameter. Thus, the time of contraction would be longer due to the obstruction to the complete vesical emptying.

However, there was not a significant statistical difference when comparing times of contraction between the urethral (CT1) and cystostomy (CT 2) catheters . This could be possibly explained by the small sample size.

If this interpretation corresponds to reality, it will lead to the assumption that another mechanism is acting to modify bladder pressure, or else, to reduce it when measured through the cystostomy. Trauma caused by cystostomy with consequent vesical irritation and reduction of the functional capacity could be one of these factors.

Urethral pressure values reported in the literature ${ }^{18}$ are larger than the ones found in the present study suggesting that the presence of the catheter in urethra acts as an obstructive factor. On the other hand, there are data showing that experimentally, the stimulation of the urethral afferent nerves may induce or stimulate contraction of the detrusor in female rats under anesthesia with urethane. ${ }^{19}$ These two studies may express contradictory beliefs, considering that the urethral stimulation leading to the contraction of the detrusor could cause an increase of the mictional frequency and consequent reduction of the contraction strength.

Urethral pressure values in profiles recorded before (UP1) and after vesical denervation (UP3) were shown to be higher than the ones with the cystostomy catheter (UP2), suggesting a difference between the two methods.

On the other hand, there was not a significant statistical difference when comparing the UP parameters before and after the bladder surgical denervation up to the colon area, demonstrating that the procedure does not significantly modify urethral function. 
However, standard deviations in urethral pressures were of a higher amplitude in female rats with denervated bladders in relation to the ones with normal ones. This fact can suggest that parasympathetic denervation can cause variations in urethral behavior in these animals. In fact, patients with chagasic cystopathy, where parasympathetic denervation occurs, showed an increase in the band of urethral work. ${ }^{20}$ However, to evaluate such hypothesis, it would be necessary to make a comparative study of chagasic and surgical denervation using bethanechol chloride injections. This was not the aim of this study but it showed a comparison of the methods in the acute phase.

Bladder surgical denervation in female rats is not possible without sectioning the ureters. But there was not a significant statistical difference between functional urethral length in female rats with normal or denervated bladders, suggesting that urethra enervation remains intact immediately after bladder surgical denervation up to the bladder neck.

The results of this study demonstrate that the methods compared show statistically different results. This could be a guide to investigators regarding the comparison of procedures involving urodynamic studies in female rats with these methodologies.

\section{Conclusions}

The methods of urodynamic evaluation employed in female rats are different. The presence of a catheter in the urethra can function as an obstructive factor to vesical emptying, causing increased bladder pressure. Vesical surgical denervation up to the bladder neck does not compromise urethral function.

\section{References}

1. Abrams P, Cardozo L, Fall M, Griffiths D, Rosier P, Ulmsten U, Van Kerrebroeck P, Victor A, Wiein A. The standardisation of terminology in to lower urinary tract function: report from the standardisation subcommittee of the International Continence Society. Urology. 2003;61:37-49.

2. Suaid HJ, Martins ACP, Rock JN, Cologna AJ, Tucci Jr S. Comparison of urethral function after simple cystectomy in female rats and cystoprostatectomy in male rats. Acta Cir Bras. 1998;13:25-9.

3. Resplande J, Graziottin TM, Gholami S, Nunes L, Lue TF. Urethral pressure profile in female rats. Morphologic and functional aspects. Braz J Urol. 2001;27:158.

4. Goldstein RE, Westropp JL. Urodynamic testing in the diagnosis of small animal micturition disorders. Clin Tech Small Animal Pract. 2005;20:65-72.

5. Fischer JR, Lane IF, Cribb AE. Urethral pressure profile and hemodynamic effects of phenoxybenzamine and prazosin in non-sedated male dogs. Canadian J Veter Res. 2003;67:30-8.

6. Kono M, Nakamura Y, Ishiura Y, Komatsu K, Kontani H, Kamiki M. Central muscarinic receptor subtype regulating voiding in rats. J Urol. 2006;175:353-7.

7. Bae JH, Jung PB, Lee JC. The effect of alphaadrenoreceptor antagonists on the urethral perfusion pressure in the female rat. Int Br J Urol. 2005;96:1131-5.

8. Rock JN, Martins APC. An experimental model cystometric evaluation in unaesthetized rats. Medicina. 1994;27:376.

9. Canonn TW, Damasser M. Effect of anesthesia on cystometry and leak point pressure of the female rat. Life Sci. 2001;27:69:1193-202.

10. Yokoyama, Yoshiyama M, Namiki, Groat WC. Influence of anesthesia $n$ bladder hyperactivity induced by middle cerebral arterial occlusion in the rat. Am J Physiol. 1997;273(6 Pt 2):R1900-7.

11. Enhorning G. Simultaneous recording of the intra vesical and intra urethral pressure. Acta Chir Scand Suppl. 1961;Suppl 276:1-68.

12. Suaid HJ, Cologna JC, Martins ACP, Tucci Jr S, Rock JN. Action of the sildenaphilcitrate on the urethral function of female rats with vesical denervation. Acta Cir Bras. 2003;18:27-9.

13. Brown M, Wickham JEA. The urethral pressure profile. Brit J Urol. 1969;41:211-7.

14. Resplande J, Graziottin TM, Nunes L, Lue TF. Comparison between the maximum urethral closure pressure and measures of the urethral resistance in female rats. Braz J Urol. 2001;27:33.

15. Gonçalves MA. Experimental model of partial obstruction of distal urethra in female rats. Ribeirão Preto: São Paulo, 2004. 73 p. Master Dissertation - Department of Surgery and Anatomy - Medicine College of Ribeirão Preto University of São Paulo.

16. Saito M, Wein AJ, Levin RM. Effect of partial outlet obstruction on contractility: comparison between severe and mild obstruction. Neurourol Urodyn. 1993; 12:573-83.

17. Starling EH. The regulation of the heart beat. J Physiol. 1914;48:465-8.

18. Baessler K, Miska K, Draths R, Schuessler B. Effects of voluntary pelvic floor contraction and relaxation on the urethral closure pressure. Int Urol J Pelvic Floor Dysf. 2005; 16:187-90.

19. Jung SY, Phrase Me, Ozawa H, Yokoyama, Yoshiyama M, Groat WC, Chancellor MB. Urethral afferent nerve 
activity affects the micturition reflex: implication for the relationship between stress incontinence and detrusor instability. J Urol. 1999;162:204-12.
20. Suaid HL, Rock JN, Martins ACP, Cologna AJ, Tucci Jr S. Modulation of Urethral Alfa-Sympathetic by Parassympathetic Before Following Bethanechol Chloride Injection. Inter Braz J Urol. 2003;29:162-5.

\section{Correspondence:}

Ana Beatriz Gomes de Souza

Rua Pernambuco, 946 - apto 202 - Ed. Park Avenue

Bairro São Francisco - Cep 79010-900 - Campo Grande, MS - Brazil.

Conflicts of interest: none Phone (67) 3321-6125 and (67) 9257-9273.

anabegs@hotmail.com

\section{How to cite this article:}

Souza ABG, Suaid HJ, Suaid CA, Tucci S. Jr, Cologna AJ, Martins ACP. Comparison of two experimental models of urodynamic evaluation in female rats. Acta Cir Bras [serial on the Internet], 2008; 23 Suppl 1. Available from URL: http://www.scielo.br/acb.

\section{Comments:}

This is an excellent article that compares two experimental models of urodynamic evaluation in female rats. The first method used an urethral catheter to record the bladder pressure and in the second method the evaluation was done using a cystostomy catheter. The authors conclude that the results were different because the urethral catheter is a obstructive fator causing increased vesical pressure. I think that this article serves as a valuable addition to the literature because many urodynamic studies in animals have been done using these methodologies.

\section{Carlos Gilberto Carlotti Junior}

$\mathrm{PhD}$, Associate Professor, Division of Neurosurgery, Department of Surgery and Anatomy, Ribeirão Preto Faculty of Medicine, University of São Paulo, Brazil.

\section{Comments:}

The relevance of urodynamic studies to the diagnostic of vesicle and urethral disorders is not to be disputed. Animal experimental models allow studies on the physiopathology and drug utilization in these diseases. The authors in this report, compared vesicle pressure by vesicle catheterization and cystostomy. Cystotomic urodynamic studies are well known but have the disadvantage of surgical manipulation, which may reduce the vesicle volume and consequent increase of micturition frequency. In urethral catheterism, on the other hand, the risk is of vesicle and urethral trauma in addition to the increase of urethral resistance but,it reproduces human urodynamic studies. Evaluation of the vesicle pressure measurements and the profile of urethral pressure led the authors of this study to verify that a catheter in the urethra may function as a resistance factor for vesicle emptying, elevating its pressure. In addition, it was verified that vesicle surgical denervation up to the vesicle neck does not compromise urethral function. The results in this study suggest that the methods, although adequate, are not equivalent. The authors rightly recommend that the choice of a experimental model for urodynamic studies should address not only the advantages but also the disadvantages of each option.

\section{Marcio Dantas}

MD, PhD, Division of Nephrology, Department of Clinical Medicine, Ribeirão Preto Faculty of Medicine, University of São Paulo, Brazil. 